We are, then, confronted with a situation which differs from the past not merely in the degree of the problems faced, but in their quite revolutionary nature as well. We now have to design for change in machines, knowing that they will change and knowing that they will fail. The material design no longer demands simply knowledge of a set of static factors, but requires information on dynamic processes with statistical characteristics. The traditional methods will certainly go on indefinitely fulfilling their purpose in many fields, and they will improve ; but if the materials barrier, as it may be called, is to be broken, a quite new philosophy of design is required. Whatever may develop in the future, it is certain that a mere scaling-up of the test resources, a continued amassing of data on individual properties, and a hand-to-mouth selection of material will be inadequate, however good the basic design may be. At present, not even the faintest framework of a solution exists ; but there is a growing awareness of the need for some part of science and engineering to concern itself with the possibilities of quite new methods of design, particularly in the selection of materials. Such studies cannot be made without getting well away from particular problems of detail and seeing the full implications of the changes as they affect the methors of testing, the nature of the test data, the extraction of empirical factors and the use of such factors in actual design. Complex testing, so far as both stress and temperature are concerned, seems likely to replace much of the single-property fixed-conditions testing at present undertaken. 'The assembly of the data into a suitable usable form is bound to be fraught with great difficulties. But computing and data-processing tech- niques have transformed similar situations elsewhere, and encourage hopes of some success in this direction as well.

We may sum up somewhat as follows. Fundamental science needs to order its ideas on the processes which occur in metals under alternating stresses, and to be more rigorous in the distinctions drawn between fatigue and other parallel processes. The theories, though superficially sound, are facile and lack the conviction which only critical experiment can give them. The bulk of applied work on fatigue continues very successfully, according to established principles, and one by one the numerous engineering factors are being run through. There is an improved agreement between different centres of research following the better design of test machines and the recognition of differences between them, but there is a real need for an infusion of statistical theory. For the future, engineering design needs to be supplemented (not replaced) by a quite different approach involving new and, at present, unknown methods, in which fatigue takes its place as one of several interacting processes which combine to bring about, inevitably, a failure of the machine.

Conferences on the scale of the one recently held in London involve a prodigious amount of work and planning, both technical and administrative, and something more than a formal acknowledgment to the bodies concerned is required. The quality of the organization does all concerned great credit, and due to their efforts a real and effective contribution has been made to the subject. The final proceedings, when published, will be on a scale quite unlike anything attempted previously, and will surely in time become established as a major work of reference.

\title{
OBITUARY
}

\section{Prof. John Garstang}

John Garstang was born in 1876 at Blackburn, where his father, Dr. Walter Garstang, was a wellknown physician. After leaving Blackburn Grammar School, he went to Jesus College, Oxford, with a mathematical scholarship, and graduated in 1899. While still an undergraduate his interest in archæology had been awakened, and from 1897 for some nine or ten years he undertook research and excavations at various sites of Roman Britain, particularly at Rib. chester, Melandra Castle, Richborough and Brough.

His first visit to Egypt was in the winter of 1900 , when he excavated at Mahasna and Bet Khallaf for the Egypt Research Account. In the following winter, supported by friends in Liverpool, he excavated on his own account in the same district. By this time he had been introduced to University circles in Liverpool, and in 1902 he was appointed honorary reader in Egyptian archæology in the University of Liverpool. During this and the following years Garstang campaigned tirelessly to stimulate interest in archæology in Liverpool. These were the years when the University was about to obtain its charter and his appeals were not ignored, for an influential group of Liverpool citizens was specially interested in ensuring that the new University should be established on broad lines. It was almost entirely due to his efforts that a sum of $£ 10,000$ was raised, and thus by 1904 premises had been secured, staff recruited, and the Liverpool Institute of Archæology was inaugurated. It was Garstang who conceived and planned the Institute, it was he who made it possible, he was its honorary secretary, and retained that office for more than forty years until the independent existence of the Institute ceased with its incorporation in the University School of Archæology and Oriental Studies. In 1907 he was appointed John Rankin professor of the methods and practice of archæology in the University of Liverpool, and held the chair until his retirement in 1941.

Although each year he did a certain amount of teaching and lecturing in Liverpool, his principal interest was in excavation. His energy was immense, and every year until 1914 saw him excavating at one or more sites in the Near East. The list of sites is formidakle : Beni Hasan (1902-4), Naqada, Hierakonpolis, Edfu (Hissaia) and Nubia (1904-6), Abydos $(1906-9)$, and Meroe in the Sudan $(1909-14)$. At Meroe he conducted the first excavations on the site and uncovered a very large section of the enormous city. Most of the results of these excavations are still unpublished; but sufficient of his records has survived to encourage the hope that in the near future it will be possible to publish reasonably full details of his results.

During these busy years Garstang found time in 1907 to make a journey of survey and exploration 
across Asia Minor. This journey was to lead to an eventual widening and reorientation of his archæological interests. Apart from his own excavations at Sakje Geuzi in 1908 and 1911 , in 1910 he published his book "The Land of the Hittites", which, together with its modernized successor "The Hittite Empire" (1929), was for many years the standard introduction to the subject.

In 1920, after a year as archæological adviser in Palestine, he became director of the British School of Archæology in Jerusalem, and the first director of the Palestine Antiquities Department. The creation and organization of that Department and of the Palestine Museum were virtually his own work, and showed his genius for organization at its best. Between 1929 and 1935 he directed excavations at Jericho : though some of his more optimistic claims, and still more those of over-enthusiastic supporters, are now no longer generally accepted, his work at Jericho greatly extended our previous knowledge and yielded results the importance of which cannot be disputed.

In 1936, thanks to a generous grant from Mr. Francis Neilson, he became director of the Neilson Expedition to the Near East. After a preliminary survey in Cilicia in 1936, during 1936-39 and again in 1947-48 he excavated the important site of Mersin in Cilicia. It was during his last campaign at Mersin that he was able to conduct the negotiations that led to the foundation of the British Institute of Archæology in Ankara. When the Institute was opened in 1948 he was appointed its first director, and in the following year he became its president, holding that office until his death. He died at Beirut on September 12, barely two days after his last visit to Mersin, where he had fulfilled his cherished wish to see once more the last site that he had discovered, and had addressed there a distinguished gathering.

Garstang was not a great academic figure and he built up no school of students; he was always the practical man and field-worker. $\mathrm{He}$ was a pioneer in many fields of archæological research. He had to an extraordinary degree a flair for discovering the good site, and once $h e$ had found that site there were few who could excel him in stimulating and sustaining general interest in the work. He had an instinctive understanding of how to appeal to the public, and his field-records and photographs show how always the propaganda side of his work was ever present in his mind. Most of his excavations, conducted in the name of the Liverpool Institute of Archæology, were carried out with the slightest of financial support : it was his gift for publicity, plus personality and untiring drive, together with loyal and generous supporters mainly in Liverpool, that year by year enabled him to open and explore new fields. It is not so much as an excavator but as an organizer that his name will live. The man whose vision and genius created organizations so diverse and so productive as the Liverpool Institute of Archrology, the Palestine Antiquities Department, and the British School of Archæology in Ankara has made a permanent contribution to archrological studies in the Near East.

H. W. FALRMAN

\section{NEWS and VIEWS}

\section{Prof. Charles Singer: Eightieth Birthday}

Charies Singer, historian of medicine and science, celebrated his eightieth birthday on November 2 . Prof. Singer can look back on a life of striving and of achievement. His historical studies grew out of his clinical and esearch work. It is now fifty-one years since, returning from an expedition to Abyssinia, where he had medical and biological experience which many young men must have envied, he published his first elinical paper. There followed years of elinical work and of laboratory research, especially on gastric carcinoma. In the same week in which Fibiger announced the discovery of the parasite for which he was awarded a Nobel Prize, Singer independently discovered this parasite. He read several communications on these subjects at the International Congress of Medicine which was held in London in 1913 , and that year saw the zenith of his writing on these subjects. Two years before that he had published his first historical paper, and from 1914 onwards he devoted himself to historical subjects. A short period at Oxford and some years in the R.A.M.C. during the First World War were followed by a post at University College, London, first as lecturer in, and later as professor of, the history of medicine. Though the years in London until his retirement in 1942 were full of great achievement, it is since that date that Prof. Singer has reaped his richest harvests. Besides several scholarly books which are of great importance in the history of medicine, he has contributed lavishly to a specialized branch of the history of the chemical industry, and for six years he has laboured on the monumental "History of
Technology", of which he was the sole begetter, and in the production of which he has shouldered the major burden. May the approaching publication of the second volume of that five-volume work stimulate him to continue making the world his debtor.

\section{Biochem stry in Birmingham : Prof. R. H. Hopkins}

Prof. R. H. Hopkins retired from the Adrian Brown chair of malting and brewing and applied biochemistry in the University of Birmingham on September 30. A graduate of that University, he has been closely associated with the Department for many years. 'Thus, he was lecturer under Prof. Adrian Brown and retained that position for several years before accepting a post at the Heriot-Watt College, Edinburgh. In 1931 he returned to Birmingham, this time as head of the Department, a position he was to occupy for twenty-five years. The retirement of Prof. Hopkins may be said to close the second epoch in the history of what was originally the British School of Malting and Brewing. In the first period, 1900-20, the School was primarily concerned with these subjects ; but already a wider field was being cultivated. In the earlier days of the second epoch a new pattern was being laid down, and in the research laboratories interest centred chiefly on the biochemistry of plant products, especially polysaccharides. A new building was occupied in 1927, and when Hopkins arrived in 1931 the time was ripe for further expansion. The ociginal raison d'être of the Department was never lost sight of, and with the advent of a group of workers from the Institute of Brewing, fundamental work on biochemical aspects of brewing and on yeast nutrition 